\title{
Coral platy fish Xiphophorus maculatus hormonal induction to improve mass spawning efficiency
}

\section{Induksi hormon untuk meningkatkan efisiensi pemijahan massal ikan plati koral Xiphophorus maculatus}

\author{
Fajar Maulana $^{1 *}$, Muhammad Zairin Jr. ${ }^{1}$, Alimuddin ${ }^{1}$, Mitra Abadi ${ }^{1}$, \\ Adhana Nur Fitrih ${ }^{1}$ \\ ${ }^{1}$ Department of Aquaculture, Faculty of Fisheries and Marine Science, IPB University, \\ Bogor, West Java, Indonesia \\ *Corresponding author : fajarmaulana@apps.ipb.ac.id
}

(Received November 13, 2019; Accepted June 16, 2020)

\begin{abstract}
Coral platy fish has a unique reproduction due to ovoviviparous (live-bearer) reproduction. The large-scale production of coral platy fish has several constraints due to the inconsistent seed birth period, which causes variations in the fry size. This makes it difficult for ornamental fish cultivators for production process efficiency and market criteria fulfillment that demands size uniformity. This study aimed to synchronize the broodstock birth period of coral platy fish by testing the hormone oxytocin and prostaglandin- $2 \alpha$ (PGF2 $\alpha$ ) through immersion methods with different durations. This study used a factorial randomized design with 21 treatments and 3 replications for each hormone type. The PGF $2 \alpha$ hormone doses used were $0 ; 0.01 ; 0.1$ and $1 \mathrm{~mL} / \mathrm{L}$, while the oxytocin hormone doses used were $0 ; 0.1 ; 0.2 ; 0.4 \mathrm{~mL} / \mathrm{L}$ with immersion duration of 4,8 , and 12 hours, respectively. The results showed that the treatment dose of $1 \mathrm{~mL} / \mathrm{L}$ PGF2 $\alpha$ for 12 hour immersion had a significant effect $(\mathrm{P}<0.05)$ compared to other treatments, the immersion group with 12 hour duration obtained a significant difference to the other treatments, both at the percentage of broodstock giving birth and the number of seeds. The hormone treatment had no significant effect on broodstock and seed survival $(\mathrm{P}>0.05)$.
\end{abstract}

Keywords: mass induction, oxytocin, prostaglandin-e $2 \alpha(\mathrm{PGF} 2 \alpha)$, mass birth, livebearer

\begin{abstract}
ABSTRAK
Ikan plati koral memiliki reproduksi yang unik karena bereproduksi secara ovovivipar (live-bearer). Produksi ikan plati koral dalam skala besar dihadapkan kendala akibat waktu kelahiran anak yang tidak serentak yang menyebabkan keberagaman ukuran anak ikan plati koral. Hal ini menyulitkan para pembudidaya ikan hias untuk efisiensi proses produksi dan memenuhi kriteria pasar yang menuntut keseragaman ukuran. Penelitian ini bertujuan untuk menyeragamkan waktu kelahiran anak induk ikan plati koral dengan uji coba pemberian hormon oksitosin dan prostaglandin-2 $\alpha$ (PGF2 $\alpha$ ) melalui metode perendaman dengan durasi waktu yang berbeda. Penelitian ini menggunakan rancangan acak faktorial dengan 21 perlakuan dengan 3 kali ulangan untuk masing-masing jenis hormon. Dosis hormon PGF2 $\alpha$ yang diuji adalah $0 ; 0,01 ; 0,1$ dan $1 \mathrm{~mL} / \mathrm{L}$, sedangkan dosis hormon oksitosin yang digunakan adalah $0 ; 0.1 ; 0.2 ; 0.4 \mathrm{~mL} / \mathrm{L}$ dengan masing-masing lama perendaman 4 , 8, dan 12 jam. Hasil yang diperoleh menunjukkan bahwa perlakuan dosis $1 \mathrm{~mL} / \mathrm{L}$ PGF2 $\alpha$ dengan lama waktu perendaman 12 jam memberikan pengaruh yang nyata $(\mathrm{P}<0.05)$ dibandingkan dengan perlakuan lainnya. Kelompok perendaman dengan durasi 12 jam memberikan perbedaan yang nyata terhadap lama perlakuan lain, baik pada parameter persetase induk melahirkan maupun jumlah anak yang dilahirkan. Perlakuan hormon tidak memberikan pengaruh yang nyata terhadap kelangsungan hidup induk dan anak yang dilahirkan $(\mathrm{P}>0.05)$.
\end{abstract}

Kata kunci: induksi massal, Oksitosin, prostaglandin-2 $\alpha$ (PGF2 $\alpha$ ), kelahiran masal, livebearer 


\section{INTRODUCTION}

Platy coral fish Xiphophorus maculatus is one of the ornamental fish from Pociliidae family, which has small size and flat shape with lengthened caudal fin in male fish as a sexual dimorphism character (Gómez-Gonzales et al., 2014). Platy fish majorly has bright colors, such as red and orange (Froese \& Pauly, 2007; Bano \& Serajuddin, 2017). This fish originates from Mexico (Dávila-Camacho et al., 2018) and introduced to around 18 countries, namely, Indonesia, Singapore, Japan, Nigeria, USA, Brazil, and Australia (Magalhães \& Jacobi, 2017), besides capable of adapting to a worse environment (Maddern et al., 2011). This fish is utilized as a larvivorous fish to handle mosquito larvae in tropical and sub-tropical countries (Surendranath et al., 2018). The market price in Indonesia ranges Rp1,000-1,500 per fish. KKP (2015) stated that the production of platy fish in Indonesia in 2014 reached 44.2 million fish and was predicted to continuously increase.

The coral platy fish include in a live-bearer fish or giving birth fish group (Froese \& Pauly, 2007; Tolon, 2018). This fish can produce seed many times during mating season; the period between pregnancy/birth is 25-35 days, averagely around 28 days (Shahjahan et al., 2013; Yang et al., 2012). Most live-bearing fish have asynchronous embryo development and birth process, therefore the embryos contained have various sizes (NorazmiLokman et al., 2016). This condition causes the inhibition of mass breeding process due to various seed sizes produced.

The embryo develops in the ovarian follicle during the developmental phase and is born as a seed (Bone \& Moore, 2007) with the next fertilization process is thought to occur after the previous birth process (Yang et al., 2012). This condition causes the seed age is varied, which potentially complicates the rearing process in terms of live feed availability, seed sustainability, mainly for the experimental requirement in the laboratories (Norazmi-Lokman et al., 2016), difficult planting pattern implementation, and unfulfilled coral platy fish demand in the international market. This condition causes inefficient production, especially in a large scale, thus requiring an effort to unify the birth period at one period.

Hormonal influence is closely related to brain cell mechanisms, mainly on the reproductive behaviour in teleost and elasmobranchii group
(Forlano \& Bass, 2011). Therefore, a certain utilization of hormones potentially becomes an effort for artificial birth. Several potential hormones utilized are prostaglandin (PGF2 $\alpha$ ) and oxytocin. The PGF $2 \alpha$ hormone acts in improving the uterus layer contraction to rapidly make the uterus contract and stimulating the nucleus in germinal vesicle that migrates into the corner part until ovulation process (Jamlaay et al., 2013; Sugimoto et al. 2015; Baek \& Lee, 2019). In the induction experiment of PGF2 $\alpha$ on snakehead broodstock fish with different doses obtained a shorter ovulation period and increased number of eggs with the dose of $0.9 \mathrm{~mL} / \mathrm{kg}$ broodstock.

In mammals, oxytocin hormone stimulates strong contraction in the uterus wall, thereby facilitating the birth process (Arrowsmith \& Wray,2014; Knobloch \& Grinevich, 2014). In fish, oxytocin hormone is reported to be utilized as an Ovaprim $^{\circledR}$ for artificial spawning process in sangkuriang catfish. The experiment of hormone administration with $75 \%$ oxytocin and $25 \%$ Ovaprim $^{\circledR}$ through broodstock injection can produce the shortest ovulation period, namely, 9 hours and 23 minutes (Mayyanti, 2013). Based on some studies above, this study was performed as an effort to unify the seed birth period of coral platy fish with different hormone inductions, namely, oxytocin and prostaglandin-2 $\alpha$ (PGF2 $\alpha$ ), through immersion bath method with different durations.

\section{MATERIALS AND METHODS}

\section{Experimental design}

The experimental design used is a factorial randomized design with two test levels, namely, different hormone types and doses with different immersion duration periods against the uniformity of broodstock birth period observed for 7 days after hormonal immersion. The hormone types used were oxytocin with the doses of $0.1 \mathrm{~mL} / \mathrm{L}$, $0.2 \mathrm{~mL} / \mathrm{L}$, and $0.4 \mathrm{ml} / \mathrm{L}$ and prostaglandin (PGF2 $\alpha$ ) with the doses of $0.01 \mathrm{~mL} / \mathrm{L}, 0.1 \mathrm{~mL} / \mathrm{L}$, and $1 \mathrm{~mL} / \mathrm{L}$, and control by adding non-hormonal treatment; each dose was tested at the immersion durations of 4, 8, and 12 hours. This study contained 21 treatments with three replications which performed serially (time-series) based on the replication of each hormone treatment. The number of broodstocks used on each replication was 10 broodstocks, thus the total number of broodstocks used was 12 broodstocks for each hormone type with different period. The hormones 
used had a hormonal injection specification for animal with the commercial brand of Oxytocin-10 $(10 \mathrm{IU})$ and Capriglandin (5.5 $\mathrm{mg}$ dinoprost tromethamine, $12.0 \mathrm{mg}$ benzyl alcohol).

\section{Experimental object}

This study used pregnant female broodstocks of coral platy fish that were ready to give birth. Pregnant broodstocks with the average weight of $2.08 \pm 0.02 \mathrm{~g}$ and average length of $4.03 \pm 0.02 \mathrm{~cm}$ were selected. These broodstocks were obtained from the ornamental fish cultivator in Parung, Bogor, West Java.

\section{Container preparation}

The container used in this study was $60 \times 40 \times 30$ $\mathrm{cm}^{3}$ aquarium as much as 12 aquaria for broodstock rearing, and $40 \times 30 \times 25 \mathrm{~cm}^{3}$ aquarium as much as 12 aquaria for larval rearing container. The aquarium disinfection was performed using $40 \mathrm{mg} / \mathrm{L}$ potassium hypochlorite and neutralized using $20 \mathrm{mg} / \mathrm{L}$ sodium thiosulfate for four hours. The aquarium was then rinsed with clear water and dried for 24 hours. Aquarium was filled with water until $25 \mathrm{~cm}$ height equipped with aeration. As an effort to minimize broodstock fed the seeds, a breeding trap modification was installed at the end part of aquarium.

The container used during immersion was $15 \times 15 \times 25 \mathrm{~cm}^{3}$ aquarium. After the container was ready, $1 \mathrm{~L}$ water was filled, then hormones were taken by syringe and distributed into the immersion aquarium based on each treatment dose. The aquarium was aerated and stood for 10 minutes. Fish were moved into the aquarium and stood based on the immersion duration treatment.

\section{Broodstock rearing}

Fish were reared in a rearing container by maintaining the optimum environmental condition. Water exchange was performed once in 2 days. Water quality measurement containing temperature, $\mathrm{pH}$, and $\mathrm{DO}$ was performed every day, whole ammonia, nitrite, and nitrate were measured once in 3 days regularly and scheduled. Fish were fed 3 times a day with Tubificidae in ad libitum method (Velasco-Santamaria \& CorredorSantamaria, 2011; ŞAHIN et al., 2017). Fish were observed their behaviours and number of seeds produced. Moreover, the broodstock survival rate was calculated at the end of rearing.

\section{Seed harvesting}

Seeds were harvested when each broodstock gave birth with 48 hour observational period. Fish seeds were carefully harvested by syphonization, then performed a total larvae calculation, before moving into a separated container to identify the larval survival rate after 10 days of rearing.

\section{Parameters}

The parameters observed in this study comprised percentage of broodstock giving birth, number of seeds, seed and broodstock survival rate, and water quality during rearing.

\section{Percentage of broodstock giving birth}

Total broodstock birth was noted every 4 hours during the observation period and accumulated at the end of the observation period. The number of seeds were noted and differed based on each broodstock.

\section{The number of seeds}

The number of seeds was calculated every 4 hours during the observation period. The number of seeds were noted and differed based on each broodstock.

\section{Survival rate $(S R)$}

The survival rate is a ratio of total living broodstock/seed at the final rearing and total fish/ seed at the initial rearing.

Note :

$$
\operatorname{SR}(\%)=\frac{\mathrm{Nt}}{\mathrm{No}} \times 100
$$

$\mathrm{SR}=$ Survival rate $(\%)$

NO = Total fish stocked during initial rearing (fish)

$\mathrm{Nt} \quad=$ Total fish living during final rearing (fish)

\section{Data analysis}

The data obtained were tabulated and analyzed. Data obtained were tabulated using MS. Excel and analyzed using analysis of variance at $95 \%$ confidence level, then continued with Tukey test using SPSS 25.0, when there is any significant different response among treatment.

\section{RESULTS AND DISCUSSION}

\section{Results \\ Percentage of broodstock giving birth (PIM)}

The percentage of broodstock giving birth (Figure 1) was obtained from the percentage of total final broodstock number that gave birth during the observation period. Based on the experiment 


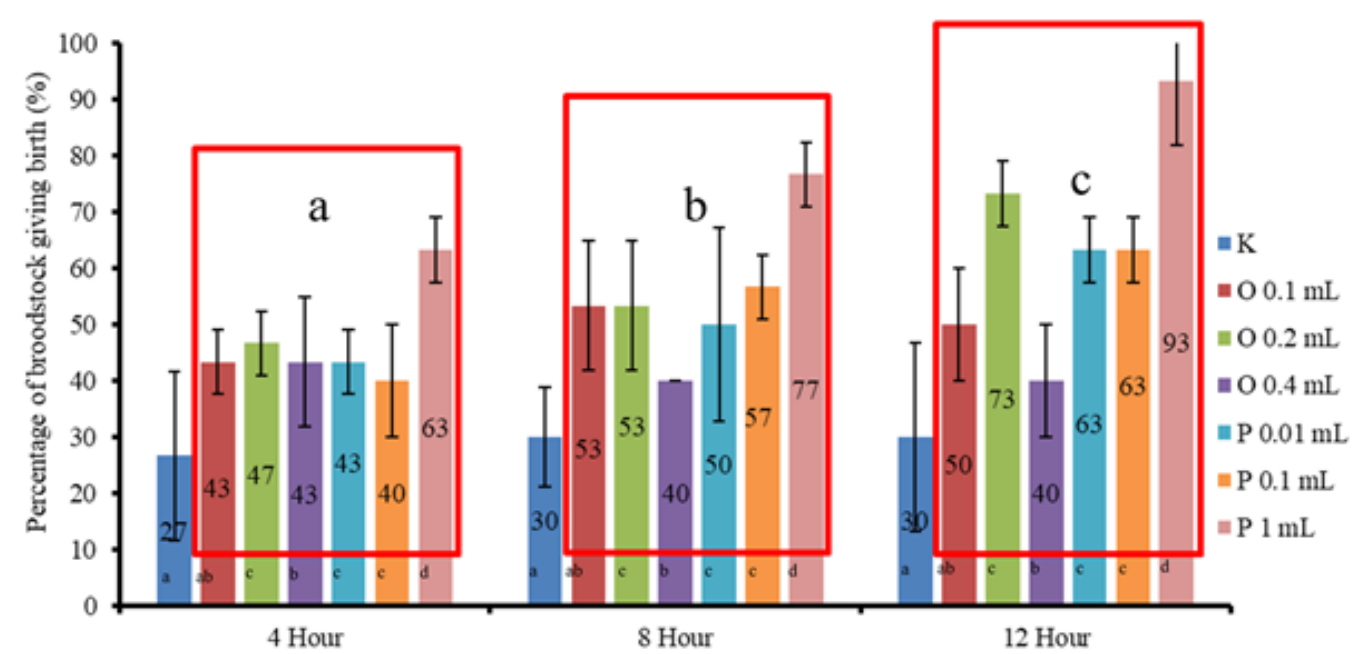

Figure 1. The percentage of coral platy fish broodstock giving birth immersed with prostaglandin and oxytocin hormones with different doses and immersion durations. Note: $\mathrm{K}$ (control), $0.1 \mathrm{~mL} / \mathrm{L}$ oxytocin, $0.2 \mathrm{~mL} / \mathrm{L}$ oxytocin, $0.4 \mathrm{~mL} / \mathrm{L}$ oxytocin; $0.01 \mathrm{~mL} / \mathrm{L}$ prostaglandin; $0.1 \mathrm{~mL} / \mathrm{L}$ prostaglandin; and $1 \mathrm{~mL} / \mathrm{L}$ prostaglandin, with the respective immersion durations of $4,8,12$ hours. Different letters on the bar show a significant difference $(\mathrm{P}<0.05)$. Values presented are the average value.

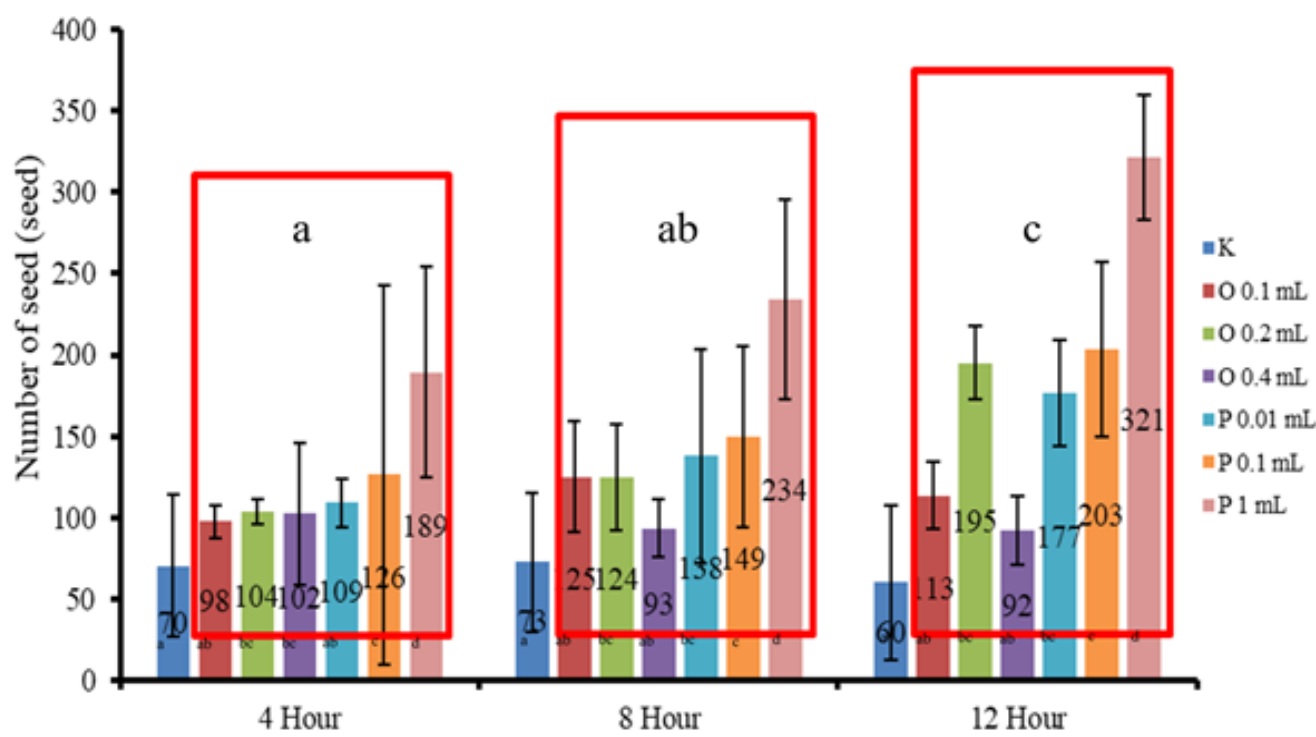

Figure 2. The number of coral platy fish $X$. maculatus seeds in 7 days after immersion. Note: $\mathrm{K}$ (control), $0.1 \mathrm{~mL} / \mathrm{L}$ oxytocin, $0.2 \mathrm{~mL} / \mathrm{L}$ oxytocin, $0.4 \mathrm{~mL} / \mathrm{L}$ oxytocin; $0.01 \mathrm{~mL} / \mathrm{L}$ prostaglandin; $0.1 \mathrm{~mL} / \mathrm{L}$ prostaglandin; and $1 \mathrm{~mL} / \mathrm{L}$ prostaglandin, with the respective immersion durations of 4, 8, 12 hours. Different letters on the bar show a significant difference $(\mathrm{P}<0.05)$. Values presented are the average value.

results, each treatment either doses or immersion duration had a significant difference $(\mathrm{P}<0.05)$ against the percentage total of broodstock giving birth. However, there was no interaction between hormones and immersion duration treatments.

\section{The number of seed}

The number of seeds produced by broodstock in each treatment is presented on Figure 2. This figure shows each treatment of hormone dose and immersion duration which was significantly different $(\mathrm{P}<0.05)$ against the number of seeds. However, there was no interaction between hormone and immersion duration factors obtained.

The survival rate of coral platy fish broodstock (SRi) and seeds (SRa)

The survival rates of coral platy fish broodstock and seeds (Table 1) were obtained from the ratio percentage of total final broodstock/seeds against total initial broodstock/seeds, as each of which 
Table 1. The survival rate of (SRi) coral platy fish $X$. maculatus in 7 days after giving birth

\begin{tabular}{cccccccc}
\hline $\begin{array}{c}\text { Broodstock survival rate } \\
(\%)\end{array}$ & $\mathrm{K}$ & $\mathrm{O} 0.1 \mathrm{~mL}$ & $\mathrm{O} 0.2 \mathrm{~mL}$ & $\mathrm{O} 0.4 \mathrm{~mL}$ & $\mathrm{P} 0.01 \mathrm{~mL}$ & $\mathrm{P} 0.1 \mathrm{~mL}$ & $\mathrm{P} 1 \mathrm{~mL}$ \\
\hline 4 hours & 100 & 100 & $100 \pm 7$ & 100 & 100 & 100 & $97 \pm 6$ \\
8 hours & 100 & 100 & $100 \pm 7$ & 100 & 100 & $97 \pm 6$ & 100 \\
12 hours & 100 & 100 & $100 \pm 7$ & 100 & 100 & 100 & 100 \\
\hline Seed survival rate $(\%)$ & $\mathrm{K}$ & $\mathrm{O} 0.1 \mathrm{~mL}$ & $\mathrm{O} 0.2 \mathrm{~mL}$ & $\mathrm{O} 0.4 \mathrm{~mL}$ & $\mathrm{P} 0.01 \mathrm{~mL}$ & $\mathrm{P} 0.1 \mathrm{~mL}$ & $\mathrm{P} 1 \mathrm{~mL}$ \\
\hline 4 hours & 80.00 & 82.00 & 77.30 & 88.00 & 83.48 & 84.94 & 82.53 \\
8 hours & 88.30 & 79.70 & 83.00 & 83.30 & 74.63 & 85.90 & 82.90 \\
12 hours & 86.00 & 83.00 & 84.30 & 84.70 & 87.57 & 87.68 & 88.47 \\
\hline
\end{tabular}

Note: K (control), $0.1 \mathrm{~mL} / \mathrm{L}$ oxytocin, $0.2 \mathrm{~mL} / \mathrm{L}$ oxytocin, $0.4 \mathrm{~mL} / \mathrm{L}$ oxytocin; $0.01 \mathrm{~mL} / \mathrm{L}$ prostaglandin; $0.1 \mathrm{~mL} / \mathrm{L}$ prostaglandin; and $1 \mathrm{~mL} / \mathrm{L}$ prostaglandin, with the respective immersion durations of 4, 8, 12 hours. There are no treatments that showed a significant difference against parameter tested $(\mathrm{P}>0.05)$. Values presented are in the average and standard deviation.

Table 2. Water quality in coral platy $X$. maculatus broodstock rearing

\begin{tabular}{|c|c|c|c|c|c|}
\hline \multirow{2}{*}{ Water quality parameter } & \multicolumn{4}{|c|}{ Treatment } & \multirow{2}{*}{ References } \\
\hline & PA & PB & PC & PD & \\
\hline $\mathrm{pH}$ & $7.3-7.5$ & $7.4-7.6$ & $7.4-7.7$ & $7.3-7.6$ & 6.5-9 (Boyd, 1990) \\
\hline Temperature $\left({ }^{\circ} \mathrm{C}\right)$ & $26-27$ & $26-27$ & $26-27$ & $26-27$ & $26^{\circ} \mathrm{C}$ (Yang et al., 2012) \\
\hline $\mathrm{DO}(\mathrm{mg} / \mathrm{L})$ & $3.6-5.7$ & $3.8-6.3$ & $3.5-6.2$ & $3.4-4.3$ & $>3$ (Boyd, 1990) \\
\hline Ammonia (mg/L) & 0.009 & 0.03 & 0.03 & 0.03 & $<3$ (Yang, 2012) \\
\hline
\end{tabular}

Table 3. Water quality in coral platy $X$. maculatus seed rearing

\begin{tabular}{|c|c|c|c|c|c|}
\hline \multirow{2}{*}{ Water quality patameter } & \multicolumn{4}{|c|}{ Treatment } & \multirow{2}{*}{ References } \\
\hline & PA & PB & $\mathrm{PC}$ & $\mathrm{PD}$ & \\
\hline $\mathrm{pH}$ & $7.4-7.6$ & $7.4-7.8$ & $7.3-7.6$ & $7.5-7.6$ & 6.5-9 (Boyd, 1990) \\
\hline Temperature $(\mathrm{C})$ & $26-27$ & $26-27$ & $25-27$ & $26-27$ & 25-27 (Boyd, 1990) \\
\hline $\mathrm{DO}(\mathrm{mg} / \mathrm{L})$ & $2.7-3.5$ & $2.3-4.1$ & $3.2-4.7$ & $3.2-4.1$ & $>3$ (Boyd, 1990) \\
\hline Ammonia (mg/L) & 0.009 & 0.009 & 0.009 & 0.009 & <1 (Zakaria, 2003) \\
\hline
\end{tabular}

was observed in 7 days after immersion and 10 days after giving birth. The fish survival rate showed no significant difference $(\mathrm{P}>0.05)$ on all treatments.

\section{Water quality parameter}

Water quality data were used as supporting data for environmental condition against broodstock and larvae of coral platy fish during study. The result data of water quality measurement is presented on Table 2 . The results of water quality observation in broodstock rearing container showed the same value on all PA treatments which are lower than other treatments. The water quality value was also in the optimum range that supported the fish life (Boyd, 1990).

The water quality observation results in seed rearing container (Table 3) during 10 days of observation showed that $\mathrm{pH}$, temperature, and ammonia was similar on all treatments that supported the fish life (Boyd, 1990). Meanwhile, the lowest range on the oxygen content for PA and PB treatment were smaller that other treatments based on the reference standard (Boyd, 1990).

\section{Discussion}

The hormone used in this study aimed to stimulate the coral platy fish broodstock to give birth. The experimental results between hormones at various doses showed a significant difference in the percentage of broodstock giving birth (Figure 1). In the administration of the oxytocin hormone, the treatment dose of $0.02 \mathrm{~mL} / \mathrm{L}$ showed a significant difference among other doses (increased by $100 \%$ compared to control), thereby can be stated that hormones play a role in 
the uterine membrane contraction and coral platy fish broodstock stimulation to give birth. This was based on Muchlisin et al. (2014) and Khajehei (2017), who stated that oxytocin is very effective in contracting arterial and venous blood vessels, making the oxytocin concentration in the blood increases greatly during giving birth. In mammals, this hormone mediates the increased uterine myometrial contractility (Maiti et al., 2011; Tica et al., 2011). Increased oxytocin hormone dose has a positive impact on the broodstock physiological condition to a certain point, then decreases or becomes negative. This was identified from the administration of $0.2 \mathrm{~mL} / \mathrm{L}$ oxytocin hormone; the percentage of broodstock giving birth decreased on all immersion durations. Several negative effects on the seeds were reported due to hormone hyperstimulation (doses/exposure period) as the increased broodstock contraction frequency (Xu et al., 2017), therefore, suspected to provide a pressure for coral platy fish broodstock, then failed to give birth.

In fish, oxytocin hormone is often used for Ovaprim ${ }^{\circledR}$ and spawnprime ${ }^{\circledR}$ mixture as a formula to accelerate the broodstock ovulation process. However, the use of $100 \%$ oxytocin in ovulation process does not provide effective results (Islami et al., 2017). This is contradictory to oxytocin hormone as the most widely used ovulation booster (Magon \& Kalra, 2011). This is because most types of fish do not have a uterus. Only fish that have an ovoviviparous reproduction type, such as coral platy fish have a uterus. The oxytocin hormone used in this study was a synthetic oxytocin hormone. The oxytocin hormone works by stimulating the uterus contractions during the birth process. Oxytocin is synthesized by the paraventricular nucleus nerve cell body which causes the smooth muscle of the uterus contract in the final phase of pregnancy (Priyadarshi et al., 2020). This makes the coral platy fish broodstock can spawn simultaneously in 48 hours after immersion.

The PGF $2 \alpha$ hormone treatment with a dose of $1 \mathrm{~mL}$ showed the best results and was significantly different from other doses (increased by $269 \%$ compared to control). This means that the PGF2 $\alpha$ hormone plays a role in the uterus layer contraction and coral platy fish broodstock stimulation to give birth. This was based on Moallem et al. (2013), who stated that the increased concentration of PGF2 $\alpha$ hormone in blood will induce the uterus layer contraction, thereby accelerating the birth process. The experimental results of all hormones with various doses indicated $1 \mathrm{~mL}$ treatment dose of PGF2 $\alpha$ hormone was the best treatment and was significantly different from other treatments. Based on this result, the administration of oxytocin and PGF2 $\alpha$ hormones can increase the birth process stimulation in coral platy fish broodstock, although the best performance was obtained from the administration of PGF $2 \alpha$ hormone as increased by $169 \%$ compared to control. The PGF2 $\alpha$ hormone is often used in animals based on the principle of the hormone administration which can lyse or degrade the corpus luteum followed by decreased progesterone secretion that causes reproductive cycle alteration (Kim et al., 2015; Plewes et al., 2020).

Along with the increased number of broodstock giving birth due to the treatment given, hormone administration also resulted in an increased number of seeds produced with a similar pattern. The administration of oxytocin hormone at 0.02 $\mathrm{mL} / \mathrm{L}$ dose showed a significant difference to other doses (increased by $108 \%$ compared to control) and indicated a decreased performance at higher doses. The similar condition occurred in the administration of PGF2 $\alpha$ hormone; $1 \mathrm{~mL}$ dose treatment had the best result and a significant difference against other doses (increased by $267 \%$ compared to control). Immersion duration had a significant difference against the increased number of seeds produced by coral platy fish broodstock. The 12-hour immersion treatment could increase the number of seeds by $40 \%$ compared to control treatment; thereby a longer hormone exposure to broodstock increases the broodstock birth stimulation (Figure 2). There was no interaction between hormone dose treatments and immersion duration associated with increased number of seeds produced by coral platy fish broodstock.

This experiment also proves that the immersion duration has a significant effect in the birth process stimulation improvement on coral platy fish broodstock. The 12 hours treatment showed a significant difference among other treatments (increased by $33 \%$ compared to control). The longer hormone exposure period, the more broodstock giving birth stimulated (Figure 1). This indicates that a longer the immersion duration to broodstock, the higher the amount of hormone absorbed by the body, resulting in the increased number of broodstock giving birth and seeds produced. However, no interaction was found between hormone dose treatment and 
immersion duration associated with the increased percentage of broodstock giving birth. Until now, there are no literatures related to the immersion duration of hormones and number of broodstock giving birth along with its mechanism. There are also no literatures stated about the relationship between the immersion duration in oxytocin and PGF $2 \alpha$ hormones. The hormones presented in the immersion medium were thought to be absorbed by the coral platy fish broodstock through gills and skin, then entered the bloodstream and circulated to the target organs. The action mechanism of the solution by the immersion method is commonly through diffusion into skin, gills and digestive organs (Pittman et al., 2013; Rosmaidar et al., 2014). This mechanism is similar to the mechanism of recombinant growth hormonal induction in carp through immersion (Ratnawati, 2012). The absorption of dissolved components in water through the gills is usually quite large. The absorption through the digestive tract is only small, although the dissolved components in water that enter through the digestive tract are quite large, while those entering through skin are relatively small. Thus, hormone doses and immersion duration greatly affect the successive hormonal action, although there was no interaction between both factors in this study.

The physiological alteration in the broodstock immersed with hormones was uterus wall contraction followed by the birth process. This could occur after PGF $2 \alpha$ and oxytocin hormones reached the required concentrations in blood as the doses used is commonly associated with the treatment duration. High doses are commonly applied in a short period, while low doses are applied in a long period (Zairin et al., 2002). This is thought to be a positive correlation factor caused by dose and immersion duration in the percentage of broodstock giving birth (Figure 1). Norambuena et al. (2012) stated that the higher PGF2 $\alpha$ hormone dose, the faster ovulation time achieved. Factors influencing the effectiveness of hormones in the body include hormone dose, hormone application, feed quality, feeding time, stress, species, and fish size (Weatherlay \& Gill, 1987; Phaseari, 2013; Sinjai et al., 2014).

The hormonal induction did not have a negative effect on the broodstock or larvae survival rate of each treatment, as observed from the survival rate of broodstock in 7 days after immersion was 90-100\% (Figure 2) and larvae was $74.63-90.29 \%$ (Table 4). On day 10, similar condition was found in Davoodi et al. (2019). The statistical test results showed that each treatment was insignificantly different $(\mathrm{P}<0.05)$. The percentage value indicated that the hormone dose was not toxic for broodstock and did not affect the broodstock behavior during observation. This condition also applied to the survival rate of seeds (SRa) which showed that the hormone induction to increase the ovulation process had no effect on the survival rate and behavior of seeds during observation. This means that hormone treatment only influences the broodstock to increase ovulation and does not have an impact on the seeds produced. The water quality in this study represented by temperature, $\mathrm{DO}, \mathrm{pH}$, and ammonia was in a normal range and tolerable by coral platy broodstock fish (Albornoz-Garzón \& Villa-Navarro, 2017) and seeds to support the broodstock and seed lives.

\section{CONCLUSION}

The results obtained from this study showed that PGF2 $\alpha$ hormone could improve the birth period uniformity with the best dose of $1 \mathrm{~mL} / \mathrm{L}$ PGF $2 \alpha$ and 12 hour immersion duration, while the oxytocin hormone administration could improve the birth period with the best dose of $0.2 \mathrm{~mL} / \mathrm{L}$ and 12 hour immersion duration (C3). From both hormones, PGF $2 \alpha$ hormone is more effective than oxytocin hormone.

\section{ACKNOWLEDGMENT}

This study was supported by the Ministry of Research and Higher Education, Republic of Indonesia Grant [No: 129/SP2H/PTNBH/ DRPM/2018].

\section{REFERENCES}

[KKP] Ministry of Marine Affairs and Fisheries. 2017. Performance Report 2016. Jakarta: Directorate General of Aquaculture (DJPB) KKP. [12 January 2020]

Albornoz-Garzón Juan G, Francisco A VillaNavarro. 2017. Range extension of the invasive fish Xiphophorus maculatus (Günther, 1866) (Cyprinodontiformes: Poeciliidae) in the upper Magdalena river basin, Colombia. Check List 13: 2149.

Arrowsmith S, Wray S. 2014. Oxytocin: its mechanism of action and receptor 
signalling in the myometrium. Journal of Neuroendocrinology 26: 356-369.

Baek HJ, Lee DS. 2019. Prostaglandin affects in vitro ovulation and $17 \alpha, 20 \beta$-Dihydroxy4pregnen-3-one production in longchin goby, Chasmichthys dolichognathus oocytes. Development \& Reproduction 23: 111-117.

Bano F, Serajuddin M. 2017. Comparative study of larvicidal efficacy of four indigenous fish with an exotic top water minnow, Gambusia affinis. Journal of Ecophysiology and Occupational Health 16: 7-12.

Bone Q, Moore RH. Biology of fishes. New York, NY: Taylor \& Francis Group; 2007.

Boyd CE. 1990. Water Quality Pond for Aquaculture. Alabama (US): Birmingham Publishing Co.

Dávila-Camacho CA, Galaviz-Villa I, LangoReynoso F, Castañeda-Chávez MR, QuirogaBrahms C, Montoya-Mendoza J. 2018. Cultivation of native fish in Mexico: cases of success. Reviews in Aquaculture 11: 1-14.

Davoodi, Farshid, and Abbas Raisi. 2019. Effects of adult sex ratio on larvae number and survival of fry in Xiphophorus maculatus (Cyprinodontiformes: Poeciliidae). Journal of Animal Diversity 1: 83-89.

Forlano PM, Bass AH. 2011. Neural and hormonal mechanisms of reproductive-related arousal in fishes. Hormones and behavior 59: 616-629.

Froese R, Pauly D, 2007. FishBase. http://www. fishbase.org[18 August 2019]

Gomez-Gonzalez AE, Velazquez-Velazquez E, Anzueto-Calvo MJ. 2014. First record of Xiphophorus clemenciae (Cyprinodontiformes: Poeciliidae) in Grijalva river basin, México. Revista Mexicana de Biodiversidad 85: 975-978.

Islami MF, Sudrajat AO, Carman O. 2017. Induction of maturation and ovulation of red fin shark fish Epalzeorhynchos frenatus in non-spawning season. Journal of Fisheries and Aquatic Studies 5: 418-424.

Jamlaay F, Maheno S W, Faqih AR. 2016. Ovulation time and ovulated eggs count of sneakehead Channa striata induced by prostaglandin $2 \alpha$ with different doses. Jurnal Akuakultur Indonesia15: 89-92.

Khajehei M. 2017. Labour and beyond: the roles of synthetic and endogenous oxytocin in transition to motherhood. British Journal of Midwifery 25: 230-238.

Kim SO, Markosyan N, Pepe GJ, Duffy DM. 2015. Estrogen promotes luteolysis by redistributing prostaglandin F2 $\alpha$ receptors within primate luteal cells. Reproduction 145: 453-464.

Knobloch HS, Grinevich V. 2014.Evolution of oxytocin pathways in the brain of vertebrates. Frontiers in Behavioral Neuroscience 8: 31.

Maddern MG, Gill HS, Morgan DL. 2011. Biology and invasive potential of the introduce swordtail Xiphophorus hellerii Heckel (Poeciliidae) in Western Australia. Aquatic Conservation: Marine and Freshwater Ecosystems 21: 282-291.

Magalhães AL, Jacobi CM. 2017. Colorful invasion in permissive Neotropical ecosystems: establishment of ornamental non-native poeciliids of the genera Poecilia/Xiphophorus (Cyprinodontiformes: Poeciliidae) and management alternatives. Neotropical Ichthyology 15: 1-13.

Magon N, Kalra S. 2011. The orgasmic history of oxytocin: Love, lust, and labor. Indian Journal of Endocrinology and Metabolism 15: 156161.

Maiti K, Paul JW, Read M, Chan EC, Riley SC, Nahar P, Smith R. 2011. G-1-activated membrane estrogen receptors mediate increased contractility of the human myometrium. Endocrinology 152: 2448-2455.

Mayyanti. 2013. The efficiency of oxytocin and ovaprim hormones at different doses in artificial spawning of sangkuriang catfish Clarias sp. [Undergraduate Thesis]: Bogor (ID): Institut Pertanian Bogor

Moallem U, Shafran A, Zachut M, Dekel I, Porrnick Y, Arieli A. 2013. Dietary $\boldsymbol{\alpha}$-linoleenic acid from flaxseed oil improved folliculogenesis and IVF performance in dairy cows, similiar to and eicosapentaenoic and docosahexaenoic acids from fish oil reproduction. African Journal of Biotechnology 146: 603-614.

Muchlisin ZA, Arfandi G, Adlim M, Fadli N, Sugianto. 2014. Induced spawning of seurukan fish, Osteochilus vittatus (Pisces: Cyprinidae) using ovaprim, oxytocin and chicken pituitary gland extracts. AACL BIOFLUX 7: 412-418.

Norambuena F, Mackenzie S, Bell JG, Callol A, Estevez A, Duncan N. 2012. Prostaglandin (F and E, 2 and 3 Series) production and cyclooxygenase (COX-2) gene expression of wild and cultured broodstock of Senegalase sole Solea senegalensis. General and Comparative Endocrinology 177: 256-262.

Norazmi-Lokman NH, Purser GJ, Patil JG. 2016. Gravid spot predicts developmental progress and reproductive output in a livebearing 
fish, Gambusia holbrooki. PLoS One11: p.e0147711.

Pittman K, Yúfera M, Pavlidis M, Geffen AJ, Koven W, Ribeiro L, Zambonino-Infante JL, Tandler A. 2013. Fantastically plastic: fish larvae equipped for a new world. Reviews in Aquaculture 5: 224-267.

Plewes MR, Hou X, Talbott HA, Zhang P, Wood JR, Cupp AS, Davis JS. 2020. Luteinizing hormone regulates the phosphorylation and localization of the mitochondrial effector dynamin-related protein-1 (DRP1) and steroidogenesis in the bovine corpus luteum. The FASEB Journal 34: 5299-5316.

Priyadarshi H, Das R, Singh AA, Patel AB, Pandey PK. 2020. Hormone manipulation to overcome a major barrier in male catfish spawning: The role of oxytocin augmentation in inducing voluntary captive spawning. Aquaculture Research 2020: 1-14.

Ratnawati P. 2012. Growth and survival of giant gourami juvenile with different immersion time of recombinant growth hormone. [Undergraduate Thesis]. Bogor (ID): Institut Pertanian Bogor.

Rosmaidar, Aliza D, Ramadhanita J. 2014. The effect of dipping time in natural methyl testosterone hormone on male forming succesiveness process of tilapia Oreochromis niloticus larvae. Jurnal Medika Veterinaria 8: 152-155.

Şahin D, Meryem ÖZ, Karsli Z, Orhan AR, Bahtiyar M. 2017. Effect of frozen white worm Enchytraeus sp. on growth of platy Xiphophorus maculatus(Günther, 1866). Aquatic Sciences and Engineering 32: 71-75.

Shahjahan RMD, Jubayer AMD, Begum RARA, Abdur Rashid MD. 2013. Breeding biology of guppy fish, Poecilia reticulata (Peters, 1859 ) in the laboratory. Journal of The Asiatic Society of Bangladesh, Science 39: 259-267.

Sinjal H, Ibo F, Pangkey H. 2014. Evaluasi kombinasi pakan dan estradiol-17 $\beta$ terhadap pematangan gonad dan kualitas telur ikan lele dumbo Clarias gariepinus.Jurnal LPPM Bidang Sains dan Teknologi 1: 97-112.

Sugimoto Y, Inazumi T, Tsuchiya S. 2015. Roles of prostaglandin receptors in female reproduction.The Journal of Biochemistry 157: 73-80.
Surendranath SV, Nesara KM, Rakesh K, Amogha KR, Naik MG. 2018. Evaluation of efficacy of platy Xiphophorus maculatus as larvivorous fish to control mosquito larvae. Indian Journal of Pure \& Applied Biosciences 6: 57-64.

Tahapari E, Dewi RRSPR. 2013. Reproduction improvement on female striped catfish Pangasianodon hypophthalmus at dry season by hormonal induction. Berita Biologi 12: 203-209.

Tica AA, Dun EC, Tica OS, Gao X, Arterburn JB, Brailoiu GC, Oprea TI, Brailoiu E. 2011. G protein-coupled estrogen receptor 1-mediated effects in the rat myometrium. American Journal of Physiology-Cell Physiology 301: 1262-1269.

Tolon MT. 2018. Determination of hobbyist preferences for livebearer ornamental fish attributes by conjoint analysis. Turkish Journal of Fisheries and Aquatic Sciences 18: 119126.

Velasco-Santamaría Y, Corredor-Santamaría W. 2011. Nutritional requirements of freshwater ornamental fish: a review. Revista MVZ Córdoba 16: 2458-2469.

Xu GF, Zhou CL, Xiong YM, Li JY, Yu TT, Tian S, Lin XH, Liao Y, Lv Y, Zhang FH, Liu ZW, Shi YY, Shen Y, Sha J, Zhang D, Zhu YM, Sheng JZ, Huang HF. 2017. Reduced Intellectual Ability in Seed of Ovarian Hyperstimulation Syndrome: A Cohort Study. EBioMedicine 20: 263-267.

Yang H, Cuevas-Uribe R, Savage MG, Walter RB, Tiersch TR. 2012. Sperm cryopreservation in live-bearing Xiphophorus fishes: seed production from Xiphophorus variatus and strategies for establishment of sperm repositories. Zebrafish 9:126-134.

Zairin MJ, Yunianti A, Dewi RRSPS, Sumantadinata K. 2002. Effect of exposure time of pregnant females guppies, Poecilia reticulata Peters, in 17a-methyltestosterone solution on sex ratio of their seeds. Jurnal Akuakultur Indonesia 1: 31-35.

Zakaria MW. 2003. Effect of different media temperatures on survival and growth rate of Nilem Osteochylus hasselti until 35 days of age. [Undergraduate Thesis]. Bogor: (ID). Institut Pertanian Bogor. 